\author{
Aleksandra Mroczek-Żulicka \\ Uniwersytet Łódzki \\ Wydział Nauk Geograficznych \\ Instytut Geografii Miast i Turyzmu \\ Zakład Geografii Rekreacji \\ aleksandra.mroczek@geo.uni.lodz.pl
}

\title{
TWÓRCZA REKREACJA A TWÓRCZE PODEJŚCIE DO ORGANIZACJI REKREACJI - STUDIUM PRZYPADKU ZAKŁADÓW PRZEMYSŁÓW TWÓRCZYCH WI-MA W ŁODZI
}

\begin{abstract}
Abstrakt: Rekreacja twórcza od wielu lat opisywana jest w literaturze przedmiotu jako jeden z rodzajów rekreacji. Niezwykle rzadko jednak przeprowadza się badania nad jej znaczeniem czy chociażby motywacją do uprawiania tego typu aktywności. Autorka podejmuje się próby skonfrontowania istniejących definicji rekreacji twórczej ze zmieniającymi się współcześnie trendami w spędzaniu wolnego czasu oraz aktywności rekreacyjnej. Celem artykułu jest podkreślenie roli twórczego podejścia do organizowania rekreacji jako szansy na pełniejsze wykorzystanie potencjału aktywności rekreacyjnej wpływającej na rozwój osobowości jednostki. Aby zobrazować walory twórczej rekreacji oraz twórczego podejścia do organizacji rekreacji, autorka dokonuje analizy studium przypadku Zakładów Przemysłów Twórczych Wi-Ma w Łodzi.
\end{abstract}

Słowa kluczowe: rekreacja, twórczość, kreatywność, twórcza rekreacja, Łódź.

\section{WSTĘP}

Przewaga publikacji naukowych dotyczących rekreacji ruchowej nad opisującymi inne formy rekreacji jest uderzająca, szczególnie $\mathrm{w}$ polskim piśmiennictwie. Autorka, dostrzegając tę dysproporcję, postanowiła dotrzeć do źródeł, w których zostały wyeksponowane inne walory aktywności rekreacyjnej aniżeli rozwój fizyczny. Kolejną zachętą do podjęcia takiej problematyki jest rosnąca popularność tzw. nauki o rekreacji i czasie wolnym (ang. leisure studies), inspirowanej zagranicznymi publikacjami. W polskiej literaturze szczególnie mocno zaakcentowane jest przez R. WINIARSKIEGO (red. 2011) humanistyczne rozumienie terminu „rekreacja”. Postuluje się, aby rekreację traktować jako aktywność człowieka, służącą zaspokajaniu jego potrzeb i aspiracji, która nie tylko dostarcza rozrywki i odpoczynku, ale wpływa też na jego osobowość. W przedmowie do książki R. WINIARSKI (red. 2011, s. 11) podkreśla, że „rekreacja, traktowana dzisiaj jako działalność twórcza, a nie tylko regeneracyjna i kompensacyjna, jest ogniwem łączącym produkcyjną konieczność pracy i konsumpcyjną przyjemność czasu wolnego".

Autorka w artykule mierzy się także ze sposobem definiowania rekreacji twórczej i konfrontuje znane klasyfikacje rekreacji z szerszym pojmowaniem przy- miotnika "twórczy", często stosowanym zamiennie z określeniem „kreatywny". Twórcze podejście do organizowania rekreacji jawi się jako remedium na zagrożenia związane ze spłyceniem funkcji rekreacji we współczesnym świecie, a jednocześnie rosnącą potrzebą kreacyjną ludzi. Mnogość inicjatyw zaobserwowanych przez autorkę $\mathrm{w}$ przestrzeni miejskiej Łodzi, zachęcających do rekreacji twórczej, stała się zachętą do naukowego eksplorowania wybranego zagadnienia. Celem autorki artykułu jest zobrazowanie na przykładzie Zakładów Przemysłów Twórczych Wi-Ma ${ }^{1}$ (dalej: ZPT Wi-Ma) twórczego podejścia do organizowania rekreacji jako szansy na pełniejsze wykorzystanie potencjału aktywności rekreacyjnej, wpływającej na rozwój osobowości jednostki.

\section{POJĘCIE REKREACJI I REKREACJI TWÓRCZEJ}

W polskiej literaturze przedmiotu pojęcie "rekreacja” najczęściej opisywane jest $\mathrm{w}$ kontekście aktywności fizycznej. Pomimo szerokiego ujmowania definicyjnego 
rekreacji, wiele publikacji skupia się na terminologii dotyczącej rekreacji ruchowej (KWILECKA, BROŻEK 2007, NAPIERAŁA, MuSZKIETA 2011, WOLAŃSKA 1971, DEMEL, HUMEN 1970, SIWIŃSKI, PluTA, red. 2010). W języku potocznym termin „rekreacja” kojarzy się przede wszystkim z aktywnością ruchową (KUNICKI 1997), jednakże „rekreacja” pochodzi od słowa łacińskiego recreo, które oznacza: ożywić, odnowić, pokrzepić, stworzyć na nowo, oraz recreatio - powrót do zdrowia, sił (WINIARSKI, red. 2011). W związku z tym jej charakter nie odnosi się jedynie do aktywności fizycznej. W pracy pod redakcją R. WINIARSKIEGO (2011) podkreśla się, że $\mathrm{W}$ naukach humanistycznych postulowane jest, aby rekreację traktować jako aktywność człowieka służącą zaspokajaniu jego potrzeb i aspiracji, która nie tylko dostarcza rozrywki i przynosi odpoczynek, ale wpływa także na osobowość. Według typologii stosowanej $\mathrm{w}$ tym opracowaniu rekreację dzieli się na fizyczną i psychiczną. W drugiej kategorii mieścić się mogą takie formy spędzania wolnego czasu, jak: realizacja hobby, turystyka, czynności kulturalno-rozrywkowe. Rekreacją jest zatem aktywność podejmowana w czasie wolnym, która wykonywana dobrowolnie, służy realizacji potrzeb odpoczynku, rozrywki, samorealizacji i samodoskonalenia. Może ona przybierać charakter rekreacji plenerowej lub uprawianej w pomieszczeniach zamkniętych. Bywa zorganizowana indywidualnie bądź instytucjonalnie (WINIARSKI, red. 2011). Niekiedy definicje rekreacji zbliżone są treściowo do klasycznej definicji czasu wolnego, obejmujące takie aspekty życia człowieka, jak: wypoczynek, rozrywka czy zajęcia doskonalące, np. samokształcenie i zajęcia amatorskie (NAPIERAŁA, MusZKIETA 2011). T. WOLAŃSKA (1971) twierdzi jednak, że rekreacji nie uprawia się bez czasu wolnego, jest ona formą wypełniającą czas wolny w sposób akceptowalny społecznie i konstruktywny dla samorozwoju jednostki. Zgodnie z popularną definicją rekreacja jest rozumiana jako wszelkie czynności podejmowane $\mathrm{w}$ celu regeneracji sił, przejawiające się w uczestniczeniu w rozrywkach kulturalnych, grach sportowych, czy też różnych formach ruchu turystycznego - po godzinach pracy lub lekcji szkolnych, poza obowiązkami społecznymi i codziennymi zajęciami domowymi (WARSZYŃSKA, JACKOWSKI 1979).

W literaturze wymieniane są także podstawowe, bezpośrednie funkcje rekreacji, będące jednocześnie kryteriami jej definiowania. M. KWILECKA i Z. BROŻEK (2007) wymieniają następujące funkcje: wypoczynkowa, wolnoczasowa, zdrowotna, ludyczna, socjalizacyjna i kompensacyjno-korektywna. Jednocześnie może ona pełnić liczne funkcje instrumentalne (pośrednie): kulturową, ideologiczną, gospodarczą, społeczną, selektywną, adaptacyjną, integracyjną i dezintegracyjną, systemową, kreacyjną, katartyczną i stymulacyjną. Autorki szeroko opisują zjawisko rekreacji w aspekcie jej pożytku dla człowieka. Określają także, jakie zasady powinno spełniać zachowanie rekreacyjne. Rekreacja ma miejsce wyłącznie w czasie wolnym, jest zajęciem atrakcyjnym, dobrowolnym i może przybierać dowolne formy w zależności od indywidualnych preferencji. Rekreacja ma służyć wypoczynkowi, mając na uwadze dobro indywidualne i społeczne, musi spełniać także warunek egalitaryzmu. Ważna jest również zasada pozytywnego zaangażowania (przyjemności). Rekreacja nie powinna jednak kolidować z pracą i gotowością do niej, lecz równoważyć wysiłek wkładany $\mathrm{w}$ pracę. Cele związane $\mathrm{z}$ realizacją wybranej formy aktywności rekreacyjnej powinny być osiągalne i realne. Autorki wymieniają także zasadę socjalizacji, rozumianą jako konieczność spełnienia dzięki rekreacji funkcji wychowawczych lub samowychowawczych, oraz regułę uspołecznienia (KWILECKA, BROŻEK 2007). Według S. TOCZEK-WERNER (2005) najważniejsze cechy rekreacji to: łatwość nauczania, możliwość zastosowania na różnym terenie, elastyczność w przestrzeganiu reguł i zasad, dostępność dla wszystkich, wszechstronność i atrakcyjność.

Wśród wielu różnorodnych klasyfikacji form rekreacji znajdują się opisy i przykłady rekreacji twórczej. K. CZAJKOWSKI (1979) oraz I. KIEŁBASIEWICZ-DROZDOWSKA (2001) wyróżnili następujące rodzaje rekreacji: fizyczna (ruchowa), twórcza, kulturalno-rozrywkowa, a także rekreacja przez działalność społeczną. Rekreacja ruchowa skupia się wokół fizycznej aktywności człowieka podejmowanej w celu wypoczynku, rozrywki i samorozwoju. Rekreacja twórcza zaś przyjmuje formy ekspresji twórczej, np. w postaci zajęć plastycznych, muzycznych, fotograficznych, modelarskich czy majsterkowania. Dzięki takim formom kształtowane jest poczucie piękna, estetyki, a człowiek wyrabia w sobie umiejętności manualne. Z kolei formy rekreacji kulturalno-rozrywkowej podnoszą poziom kulturalny człowieka i służą rozrywce. Przykładami mogą być wszelkie imprezy kulturalne, artystyczne, gry i zabawy intelektualne, udział w życiu kulturalnym - np. wyjścia do kina lub teatru. Rekreacja przez działalność społeczną służy wyzwalaniu umiejętności organizacyjnych, dzieleniu się swoim czasem wolnym (CZAJKOWSKI 1979). Z kolei M. KWILECKA i Z. BROŻEK (2007) opisują znaczenie rekreacji twórczej jako takiej, która angażuje kreatywną stronę osobowości człowieka, stanowiącą kanał emocjonalnego oczyszczenia się. Według M. Napierały i R. Muszkiety dzięki połączeniu rekreacji twórczej i fizycznej można mówić o pełniejszym kształtowaniu osobowości człowieka (NAPIERAŁA, MUSZKIETA 2011).

W polskiej literaturze przedmiotu można odczuć deficyt opisu badań dotyczących rekreacji twórczej. Podczas studiowania dostępnej literatury autorce nie udało się znaleźć żadnych współczesnych opracowań obejmujących to zagadnienie. Dodatkowo autorka sko- 


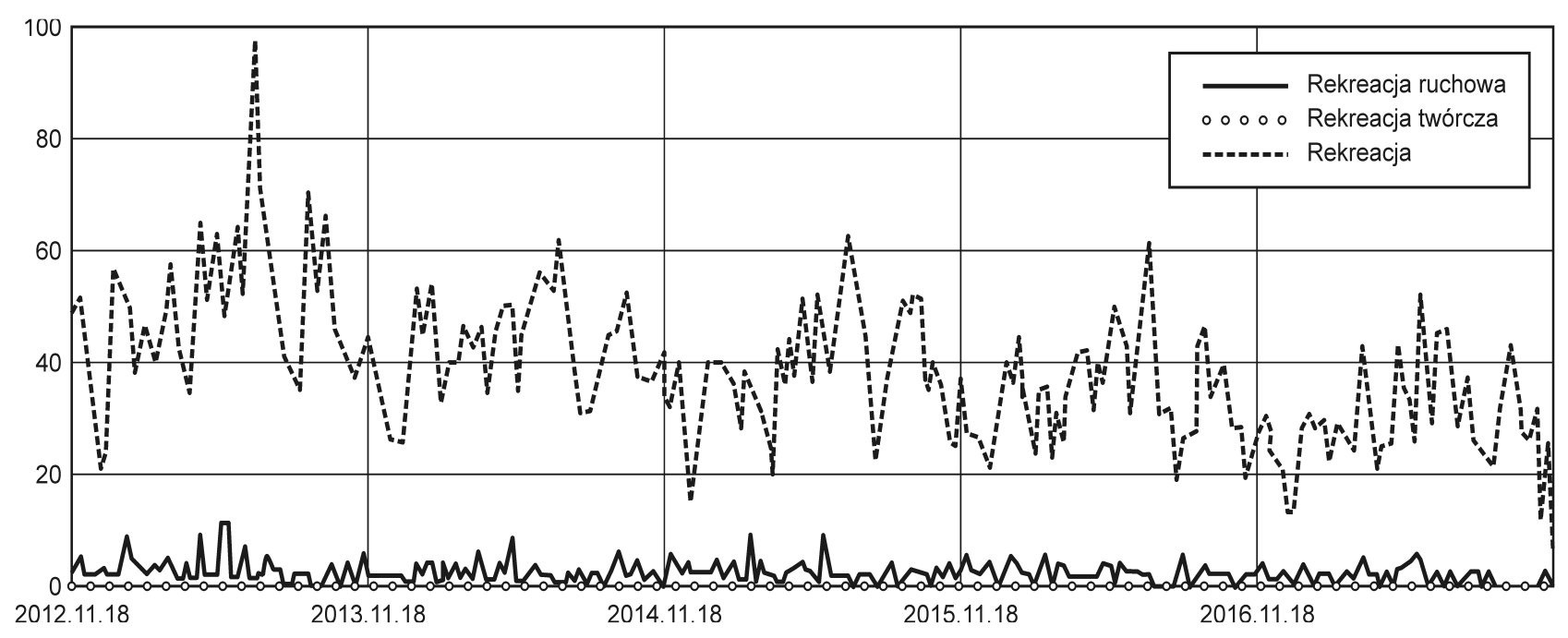

Rys. 1. Częstość wpisywania w wyszukiwarkę Google w Polsce w latach 2012-2017 zapytań dotyczących następujących określeń: „rekreacja twórcza”, , „rekreacja ruchowa” (fizyczna) i „rekreacja”

Źródło: opracowanie własne na podstawie serwisu Google Trends

rzystała z serwisu Google Trends (https://trends. google.pl), w którym udostępniane są informacje na temat liczby, pochodzenia, zależności od czasu i głównych regionów zapytań kierowanych do wyszukiwarki Google. Dzięki temu udało się porównać częstość wpisywania w ciągu ostatnich pięciu lat w Polsce zapytań: „rekreacja twórcza”, „rekreacja ruchowa” i „rekreacja”. Na rys. 1. widać zdecydowaną przewagę wyszukiwania hasła "rekreacja” nad poszukiwaniem wybranych jej rodzajów. Z kolei liczba wyszukiwań określenia „rekreacja twórcza” była na tyle mała, że nie znaleziono żadnych informacji na ten temat w opisywanym serwisie Google Trends.

W zagranicznym piśmiennictwie zjawisko rekreacji częściej odnoszone jest do aktywności w czasie wolnym (ang. leisure, fr. loisir), a badania w tym zakresie nazywane są leisure studies i leisure sciences (BACHVAROV, DZIEGIEĆ 2005). Badacze zagraniczni podkreślają, że istnieje istotna różnica $\mathrm{w}$ pojmowaniu czasu wolnego: po pierwsze funkcjonuje on jako kategoria czasu (ang. free time, fr. le temps libre), po drugie czas wolny rozumiany jest $\mathrm{w}$ sposób bardziej złożony - jako czas, bogactwo form aktywności i doświadczenia z nimi związane (ang. leisure, fr. loisir) (Kelly 1996). Przegląd definicji czasu wolnego można odnaleźć w podręczniku CH. RojeK, S.M. SHAW, J. VeaL (ed. 2006), w którym poza definicjami to zagadnienie jest rozpatrywane też $\mathrm{w}$ odniesieniu do czasu, edukacji, sztuki i rozrywki. W krajach zachodnich termin leisure był najczęściej stawiany w opozycji do "czasu pracy”, jednocześnie wyróżniany był także "okres czasu”, niepasujący do żadnej z tych kategorii. Wraz ze zmieniającym się sposobem pracy zmienia się także czas wolny (HuNNICUTT 2006). Z socjologicznego punktu widzenia obejmuje on różne formy aktywności, które człowiek wybiera w sposób dobrowolny, aby wypełnić czas pozostały po wykonaniu wszystkich obowiązków (VAN DER POEL 2006).

Powyższa definicja podobna jest do stosowanej odnośnie do tego pojęcia w polskojęzycznej literaturze. Jednak biorąc pod uwagę tematykę niniejszego artykułu, warto zwrócić uwagę na pojawiające się we wspominanym podręczniku (RoJeK, SHAW, VEAL, red. 2006) sformułowania dotyczące twórczego czasu wolnego. Wraz ze wzrostem popularności tzw. przemysłu kreatywnego oraz wzmocnienia jego relacji $\mathrm{z}$ "przemysłem" kultury, to on przejmuje rolę tradycyjnie rozumianego przemysłu czasu wolnego. Podkreślana jest konieczność debaty nad dostępem do tego typu usług oraz nowym pojęciem twórczego czasu wolnego (creative leisure) (STEVENSON 2006). S.E. IsO-AHOLA, E. JACKSON, E. DUNN (1994) stwierdzają, że nastąpił znaczny wzrost liczby osób rozpoczynających działalność twórczą, taką jak: uczęszczanie na kursy, wolontariat lub twórcze działania $\mathrm{w}$ domu, $\mathrm{w}$ tym m.in.: rzemiosło, ogrodnictwo, gra na instrumentach muzycznych. Udział w tych zajęciach jest godnym uwagi elementem spędzania wolnego czasu, przynoszącym uczestnikom poczucie spełnienia. Zajęcia rekreacyjne mogą zapewnić przestrzeń dla twórczej ekspresji, której może brakować w innych, bardziej wymagających sferach życia (CREEK 2008).

W zagranicznej literaturze pojawiają się nieliczne opisy badań dotyczących twórczej rekreacji. J. WHITING i K. HANNAM (2015) dostrzegają deficyt publikacji zawierających opis związków pomiędzy twórczością, ekspresją siebie i praktykami spędzania wolnego czasu. We wspomnianym artykule przedstawiają wyniki badań jakościowych nad życiem użytkowników przestrzeni czasu wolnego (leisure space), „prowincjonalnej 
bohemy" w dolinie Ouseburn (w Newcastle), określanej jako centrum przemysłu kreatywnego w postindustrialnej przestrzeni. Zaobserwowali oni wzrost popularyzacji twórczych form spędzania wolnego czasu, a co za tym idzie odrzucania masowej i przypuszczalnie biernej formy jego konsumpcji przez badanych. Tym samym uczestnicy badania określali czas wolny jako sferę aktywności twórczej i możliwości rozwijania autoekspresji. Zwrócili jednak uwagę na trudność w odróżnieniu czasu wolnego i czasu pracy z uwagi na fakt przenikania się aktywności zawodowej z wolnoczasową. Autorzy podkreślają, że kreatywność w czasie wolnym może przybierać różne formy i niekoniecznie musi być związana ze stylem życia artystów i klasy kreatywnej. O rekreacji, czy też czasie wolnym w kontekście koncepcji miast kreatywnych pisała D. STEVENSON (2006). Badaczka twierdziła, że aktywność rekreacyjna jest często organizowana w specjalnych, rozrywkowych i kreatywnych strefach, a jej potencjał rozwoju jednostek może przełożyć się na lepszą jakość życia codziennego mieszkańców miast.

Interesujące badania na temat roli motywacji uczestnictwa w twórczych zajęciach w czasie wolnym (creative leisure) przeprowadziła A. SALERNO (2009), podkreślając jednocześnie konieczność poszerzania studiów nad tym zagadnieniem. Inne badania przeprowadzone zostały przez R. TRNKA, M. ZAHRADNIK i M. KUŠKA (2016), a ich celem było poznanie, w jaki sposób kreatywność emocjonalna, mierzona za pomocą specjalnego narzędzia, jest powiązana $\mathrm{z}$ realnym zaangażowaniem $\mathrm{w}$ różne typy twórczych form spędzania czasu wolnego oraz z czterema kategoriami kierunków studiów. Warto przytoczyć rodzaje twórczej aktywności rekreacyjnej, analizowane w tym badaniu - były to: pisanie wierszy lub prozy (w tym blogów), komponowanie muzyki lub wykonywanie improwizacji muzycznej lub tanecznej, malowanie obrazów lub podejmowanie innej działalności artystycznej, takie jak: robienie rzeźb lub ceramiki, wszelkiego rodzaju działania typu „zrób to sam”. Opisane badania mogą stanowić inspirację do nowych studiów w tej dziedzinie w Polsce oraz do zestawienia opisów ich wyników z istniejącymi już publikacjami.

\section{TWÓRCZOŚĆ I KREATYWNOŚĆ A REKREACJA}

W opinii autorki określenia „bycie twórczym” czy „bycie kreatywnym” często postrzegane są jako synonimiczne. W polskiej literaturze definicję kreatywności, rozumianej jako cecha ludzka, spopularyzował E. NĘCKA (2001, s. 19), według którego „kreatywność przejawia się zwykle $\mathrm{w}$ jakiejś formie obserwowalne- go zachowania, polegającego na produkcji nowych i wartościowych wytworów". Podobnie znaczenie tego słowa pojmuje także K.J. SzMIDT (2013, s. 53), według którego „kreatywność to zdolność człowieka [podkreślenie autorki] do w miarę częstego generowania nowych i wartościowych wytworów (np.: rzeczy, idei, metod działania)". Z kolei twórczość dotyczy działalności [podkreślenie autorki] przynoszącej wytwory - zarówno dzieła sztuki, jak i sposoby postrzegania świata - których cechą charakterystyczną jest nowość i wartościowość (estetyczna, użytkowa, etyczna, poznawcza), chociażby dla samego podmiotu tworzącego, a człowiek o rozwiniętej postawie twórczej potrafi generować pomysły i realizować je. Ponadto twórczość w przeciwieństwie do kreatywności może być rozpatrywana w czterech aspektach, jako: 1) cecha wytworu, 2) proces psychiczny, 3) cecha osoby oraz 4) zespół czynników zewnętrznych (SzMIDT 2013). Na przykład możemy mówić o twórczym plakacie, twórczym procesie, twórczym człowieku, czy też twórczej szkole (rozumianej jako środowisko działania uczniów i pracowników). Z przytoczonych definicji wynika, że kryteriami twórczości są nowość i wartościowość, choćby nowo powstałego produktu turystycznego. E. NĘCKA (2001) wyróżnił natomiast pięć kryteriów oceny twórczego wytworu. Pierwsze z nich - trafność - dotyczy sensu istnienia stworzonego produktu oraz tego, czy trafia on $\mathrm{w}$ zapotrzebowanie odbiorców. Drugie kryterium - oryginalność - zakłada, że nie może on być wzorowany na już istniejących produktach. Trzecie to niezwykłość, oznaczająca, że ważne jest, aby wytwór statystycznie rzadko występował w danym kontekście historycznym i społecznym. Nieuchronność pojawienia się podobnego wytworu to czwarte kryterium. W piątym mowa jest o wartości estetycznej wytworu, który powinien być spójny wewnętrznie oraz nacechowany prostotą i elegancją (NĘCKA 2001).

W aktualnych publikacjach dotyczących rekreacji ich autorzy uwypuklają konieczność redefiniowania tego zjawiska. Jak zauważa Z. KRAWCZYK (2007), konieczne jest ukierunkowanie modelu rekreacji na zaspokajanie potrzeb kreacyjnych ludzi. Rekreację we współczesnym świecie interesująco opisał R. WINIARSKI (red. 2011). Człowiek w erze postindustrialnej $\mathrm{w}$ czasie wolnym ma inne potrzeby i realizuje odmiennie cele niż w przeszłości. Czas wolny charakteryzuje się płynnością, mobilnością i powszechnością, co z kolei wpływa decydująco na sposób pojmowania istoty i celów rekreacji. Współcześnie rekreacja staje się źródłem przyjemności, nowych wrażeń i emocji (WINIARSKI, red. 2011). M. KWILECKA i Z. BROŻEK (2007) zauważają jednak, że najważniejsza stała się potrzeba rozrywki i zabawa, natomiast realizacja indywidualnych zainteresowań oraz formy aktywności o charakterze twórczym, intelektualnym i poznawczym zeszły na 
dalszy plan. Jak dodaje J. MOKRAS-GRABOWSKA (2015), coraz częściej można zaobserwować podążanie za modą na realizowanie konkretnych form aktywności rekreacyjnej, co prowadzi do spłycenia funkcji rekreacyjnej. Takie podejście może zaprzeczać jej dobrowolnemu charakterowi. Co więcej, rekreacja może stać się dobrem nabywalnym - sposobem zaspokojenia potrzeb konsumpcyjnych zamiast wartością autoteliczną.

Twórcze podejście do organizowania rekreacji może stanowić remedium na wyżej opisane zmiany i zagrożenia. Biorąc pod uwagę kryteria twórczego wytworu, tego rodzaju podejście może $\mathrm{z}$ jednej strony stworzyć ludziom możliwość realizacji interesujących przedsięwzięć rekreacyjnych, a z drugiej zapewniać jej wartościowy i rozwijający charakter. Przegląd literatury zagranicznej oraz obserwowalne zjawiska społeczne wydają się wystarczającą inspiracją do podjęcia dalszej dyskusji nad aktualizacją pojęcia „rekreacja”, a przede wszystkim - „rekreacja twórcza”. Konieczne wydaje się poszerzenie form rekreacji twórczej do występujących obecnie w realiach życia społecznego. Warto także zauważyć korzyści wynikające z poszerzenia znaczenia pojęcia rekreacji twórczej. Według definicji słownikowej to, co „twórcze”, dotyczy procesu tworzenia, twórców, wiąże się z szeroko rozumianą sztuką, lecz jako synonim odnosi się do człowieka - "twórczy człowiek”, czyli konstruktywny, kreatywny, płodny, bądź "twórczy pomysł”, "twórcza praca”, czyli koncepcyjna, kreatywna (https://sjp.pwn.pl). Jednak to drugie wskazane rozumienie znajduje odniesienie w języku angielskim, gdzie "twórcza rekreacja” tłumaczona jest jako creative leisure/recreation, co powoduje trudności w przypadku porównania literatury zagranicznej z polską. Przez powyższą lingwistyczną niespójność dodatkowo akcentowana jest konieczność aktualizacji definicji twórczej rekreacji wobec zmieniającego się życia społecznego.

\section{STUDIUM PRZYPADKU}

W celu zobrazowania problematyki artykułu stworzono studium przypadku. Głównym celem tej metody badań jest opis najczęściej jednorazowego, jedynego w swoim rodzaju badanego zjawiska (BABBIE 2007). Wybór tej metody jest często dokonywany na skutek zainteresowania badacza konkretnym przypadkiem. To właśnie naukowiec decyduje, jakie zastosuje techniki badawcze (STAKE 2009). Dzięki temu możliwa jest realizacja najważniejszego celu studium przypadku, czyli jak najlepsze zrozumienie wybranego zjawiska zamiast stosowania uogólnień na podstawie tego typu badań (tamże).

Autorka przygotowała studium przypadku na podstawie analizy stron internetowych, na których opi- sano przedsięwzięcia organizowane w ZPT Wi-Ma w Łodzi, oraz indywidualnego wywiadu swobodnego, przeprowadzonego z prezesem zarządu. Aby możliwie najlepiej poznać specyfikę wybranego miejsca, zastosowano rodzaj wywiadu prowadzonego metodą opisaną przez S. KvALE (2010). Wyróżnił on siedem etapów w pełnym procesie prowadzenia wywiadu: określenie tematu, projektowanie, prowadzenie wywiadu, transkrypcja, analiza, weryfikacja oraz raportowanie (KVALE 2010). Jakościowe badania terenowe pozwalają na obranie przez badacza całościowej perspektywy (BABBIE 2007). Dzięki temu zyskuje on szansę na głębsze i pełniejsze zrozumienie badanego zjawiska. Niekiedy wywiad swobodny przyrównuje się do rozmowy, podczas której osoba prowadząca nadaje ogólny kierunek i podkreśla interesujące ją tematy poruszane przez interlokutora (KONECKI, CHOMCZYŃSKI 2012). Pozytywne nastawienie rozmówcy do prowadzonego badania sprzyjało zadowalającemu wykorzystaniu wywiadu i pozwoliło zminimalizować dystans pomiędzy badaczem a rozmówcą. Przed przystąpieniem do pracy przygotowano dyspozycje do wywia$\mathrm{du}$, a sama rozmowa była rejestrowana, co umożliwiło przeprowadzenie wnikliwszej analizy zebranego materiału. Następnie dokonano transkrypcji wywiadu. W efekcie zebrane dane poddane zostały analizie jakościowej.

\section{STUDIUM PRZYPADKU ZAKŁADÓW PRZEMYSŁÓW TWÓRCZYCH WI-MA W ŁODZI}

Aby zobrazować potencjał twórczej rekreacji oraz twórczego podejścia do organizacji rekreacji, autorka dokonała analizy proponowanych wydarzeń w ZPT Wi-Ma w Łodzi. Wybór miejsca wynika z faktu, że $\mathrm{w}$ opinii autorki w Łodzi można dostrzec wzrost znaczenia aktywności pobudzającej i rozwijającej twórczość mieszkańców tego miasta. Dokonana obserwacja aktualnej sytuacji miasta uwypukla trend w promocji Łodzi, ukazywanej jako miasto kreatywne. W roku 2012 przez Radę Miejską Łodzi została uchwalona "Strategia zintegrowanego rozwoju Łodzi 2020+", w której nakreślono następującą wizję Łodzi: „[Miasto] Przyjazne, twórcze i dynamiczne. Miasto zrównoważonego rozwoju o konkurencyjnych warunkach życia, pracy i inwestowania, wykorzystujące swój historyczny, infrastrukturalny i kreatywny potencjał" (http://uml.lodz.pl/). Ponadto w tym samym roku rozpoczęto realizację projektu pod nazwą „Promocja marki «Łódź - Centrum Przemysłów Kreatywnych»" (http://www.kreatywna.lodz. $\mathrm{pl} /$ ). Stało się to przyczynkiem do stworzenia m.in. 
wielu spotów reklamowych promujących Łódź jako centrum przemysłu kreatywnego. Powstał także System Identyfikacji Wizualnej oznaczony logo z napisem: „Łódź kreuje”. Coraz częściej dostrzegane są w przestrzeni miejskiej działania nawiązujące do kreatywności. Przykładami mogą być: plebiscyt na najlepsze łódzkie kreatywne kawiarnie, liczne warsztaty (np. kreatywnego gotowania czy wytwarzania mebli z surowców wtórnych). Wzrasta też liczba przedsiębiorstw w sektorze przemysłów kreatywnych². Powyższe inicjatywy najczęściej kumulują się w jednym fragmencie przestrzeni - często realizowane są w postindustrialnych wnętrzach fabryk i specyficznej, łódzkiej tkance miasta, np. Off Piotrkowska, Piotrkowska 217, Zakłady Przemysłów Twórczych Wi-Ma, Art Inkubator (MOKRAS-GRABOWSKA 2014). Stają się one z jednej strony swoistą marką, przyciągającą kreatywne jednostki, a z drugiej - przestrzenią do uprawiania i rozwijania twórczości codziennej mieszkańców, w tym także do organizacji aktywności rekreacyjnej.

\subsection{WI-MA KIEDYŚ I WSPÓŁCZEŚNIE}

Aktualnie Zakłady Przemysłów Twórczych Wi-Ma w Łodzi promują się jako: „60 $000 \mathrm{~m}^{2}$ postindustrialnej powierzchni. Muzyka, film, fotografia, sztuki plastyczne. Sale prób, pracownie, studia. Fundacje, spółdzielnie socjalne, firmy. Ludzie [wytłuszczenie oryginalne]. Głównie ludzie i ich pasje". (http://Wi-Ma. $\mathrm{pl} /$ miejsce/, 8.11.2017). Historycznie jednak Widzewskie Zakłady Przemysłu Bawełnianego Wi-Ma SA, znajdujące się przy alei Piłsudskiego 135 i funkcjonujące pod tą nazwą jeszcze do niedawna, to przedsiębiorstwo powstałe w latach 70. XIX w. Fabrykę włókienniczą założył przy tzw. szosie rokicińskiej Juliusz Kunitzer, znany później jako jeden z królów bawełny. Po 1922 r. zakład ten, nazywany Widzewską Manufakturą (Wi-Ma), zaczął się dynamicznie rozrastać i stał się wielobranżowym przedsiębiorstwem. Po II wojnie światowej Wi-Ma została przejęta przez skarb państwa, w wyniku czego w 1949 r. utworzono z niej trzy samodzielne przedsiębiorstwa: Widzewskie Zakłady Przemysłu Bawełnianego im. 1 Maja, Widzewską Fabrykę Maszyn Włókienniczych „Wifama” oraz Zakłady Przemysłu Włókien Sztucznych „Anilana” (BONISŁAWSKI, PODOLSKA 2008). W związku z dużą konkurencyjnością rynku azjatyckiego zakłady bawełniane w 2009 r. zaprzestały produkcji. W zadłużonej pod koniec swojej działalności firmie z 300 zatrudnionych pracowników pozostało tylko siedmiu, w tym prezes Stanisław Zaręba. Aktualnie Widzewska Manufaktura to strefa działań alternatywnych, wykorzystująca pofabryczne przestrzenie, otwarta na artystyczne fundacje, spółdzielnie socjalne i firmy. Odbywają się tutaj koncerty, wystawy, spektakle. Miejsce to pełni także funkcję pleneru filmowego oraz fotograficznego (ZARADKIEWICZ 2014). Wraz ze zmianą szyldu na budynku fabryki, 1 października 2016 r., Zakłady Przemysłu Bawełnianego po pięciu latach oficjalnie zostały przekształcone w Zakłady Przemysłów Twórczych (http:/ / www. dzienniklodzki.pl).

Przestrzeń Wi-Ma jest zajmowana przez różnego rodzaju przedsiębiorstwa, stowarzyszenia, których liczba oraz charakter działalności zmieniają się z biegiem czasu. Aktualnie na stronie Wi-Ma (http:/ /Wi-Ma.pl/ category/spis_firm) widnieje spis firm wynajmujących tam lokale na swoją działalność, są to np. kancelaria adwokacka czy biura rachunkowe. Szczególne miejsce zajmuje jednak opis firm z tzw. branży kreatywnej (http://Wi-Ma.pl/category/branza_kreatywna), które często proponują $\mathrm{w}$ pofabrycznej przestrzeni podjęcie interesujących form aktywności rekreacyjnej. Są to m.in.:

1) 3D Event - firma organizująca widowiska 3D;

2) Akademia Rytmu Folk’n'Roll - szkoła nauki gry na bębnach zachodnioafrykańskich;

3) Alfa Laser Game - organizująca paintball laserowy w budynkach Wi-Ma i w plenerze;

4) Atelier Lunlun - pracownia artystyczna;

5) Bajkonur - niezależny inkubator muzyczny, posiadający sale prób, studio nagrań, scenę koncertową i kawiarnię;

6) FabLab Łódź - otwarty warsztat technologiczny, zajmujący się obróbką materiałów drewnianych, metalowych i polimerowych;

7) fARTownia - pracownia sztuki użytkowej;

8) Indygo - studio plastyczne;

9) PackshotMe - firma specjalizująca się w fotografii produktu, prowadząca także warsztaty fotograficzne;

10) Soap Opera - pracownia mydlarska;

11) Soyuz Studio - studio nagrań, w którym wykorzystuje się techniki analogowe i cyfrowe;

12) Studio Rysunku Kreska - szkoła, w której prowadzone są warsztaty i lekcje rysunku;

13) Teatr "Zamiast” - organizujący przedstawienia, warsztaty oraz laboratorium pracy aktorskiej;

14) WJTeam - produkcja filmowa obejmująca poklatkową animację lalkową, film aktorski, reklamę, teledyski.

Przegląd wydarzeń z 2017 r. przedstawiony na stronie internetowej Wi-Ma prezentuje się dość skromnie i wydaje się, że nie oddaje panującej tam atmosfery (http://Wi-Ma.pl/category/aktualnosci). W zakładce "aktualności" znajduje się opis dwóch przedstawień, które zostały wystawione w Teatrze "Zamiast": 28.10.2017 r. zaproponowano monodram "Schron", według opowiadania Franza Kafki, a 7 oraz 8.01.2017 r. - zimowy spektakl taneczny dla dzieci "Zawirowanki”. $\mathrm{Na}$ stronie profilowej Wi-Ma w portalu Facebook (https://www.facebook.com/pg/wima.hq/events...) 
Tab. 1. Wybrane wydarzenia organizowane w Wi-Ma w 2017 r.

\begin{tabular}{|c|c|c|c|c|}
\hline Lp. & Data & Organizator & Nazwa wydarzenia & Aspekt twórczy \\
\hline 1. & Cały rok & $\begin{array}{l}\text { Akademia Rytmu } \\
\text { Folk'n'Roll }\end{array}$ & „Smyki Afryki” & $\begin{array}{l}\text { Warsztaty bębniarskie dla dzieci } w \text { dwóch } \\
\text { przedziałach wiekowych: od } 3 \text { do } 5 \text { i od } \\
6 \text { do } 10 \text { lat. }\end{array}$ \\
\hline 2. & 23-27.01.2017 & $\begin{array}{l}\text { Indygo Studio } \\
\text { Plastyczne }\end{array}$ & $\begin{array}{l}\text { Kreatywne ferie z elektrycznością } \\
\text { i robotyką }\end{array}$ & $\begin{array}{l}\text { Połączenie aktywności plastycznej z elek- } \\
\text { trycznością i robotyką. }\end{array}$ \\
\hline 3. & 14.02 .2017 & Teatr „Zamiast” & Premiera filmu „\#Love" & $\begin{array}{l}\text { Pokaz premierowy filmu krótkometrażo- } \\
\text { wego, który jest kontynuacją spektaklu } \\
\text { \#DBRMPP. Wydarzenie połączone z pre- } \\
\text { zentacją filmu niespodzianki - historycz- } \\
\text { nego spojrzenia na filmową miłość. }\end{array}$ \\
\hline 4. & 5.03 .2017 & $\begin{array}{l}\text { Off Wedding: Alter- } \\
\text { natywny Targowy } \\
\text { Meetup Ślubny }\end{array}$ & $\begin{array}{l}\text { Off Wedding Targi Ślubne Alterna- } \\
\text { tywnie }\end{array}$ & $\begin{array}{l}\text { Targi ślubne, na których są promowane } \\
\text { nowe trendy, odmienne podejście do ślubu } \\
\text { i niszowe produkty i usługi. }\end{array}$ \\
\hline 5. & 19.05 .2017 & FabLab Łódź & Noc Wytwórców & $\begin{array}{l}\text { Wieczorowe pokazy niecodziennych pro- } \\
\text { jektów i technologii łódzkiego środowiska } \\
\text { wytwórców, konstruktorów i projektantów } \\
\text { z pasją. }\end{array}$ \\
\hline 6. & $10-11.06 .2017$ & $\begin{array}{l}\text { Indygo Studio } \\
\text { Plastyczne }\end{array}$ & Weekendowy plener w Wi-Ma & $\begin{array}{l}\text { Wykorzystanie terenu pofabrycznego oraz } \\
\text { terenu zieleni na plener malarski. }\end{array}$ \\
\hline 7. & 1.07 .2017 & FabLab Łódź & Warsztaty tapicerstwa i renowacji & $\begin{array}{l}\text { Dwudniowe warsztaty z Mistrzem Rze- } \\
\text { miosła. Szkolenie realizowane metodą } \\
\text { mistrz-uczeń z naciskiem na praktykę. }\end{array}$ \\
\hline 8. & 8.09 .2017 & $\begin{array}{l}\text { Centrum Dialogu } \\
\text { im. Marka Edel- } \\
\text { mana }\end{array}$ & $\begin{array}{l}\text { Imprezy towarzyszące Festiwalowi } \\
\text { Czterech Kultur w Łodzi: Dzień } \\
\text { Otwarty Pracowni Kreatywnych, } \\
\text { przedstawienie „Oplątane” grupy } \\
\text { LineAct oraz „Mokosh” - odsłonięcie } \\
\text { muralu Nomad Clan }\end{array}$ & $\begin{array}{l}\text { Aktywność kulturalna związana z ekspre- } \\
\text { sją twórczą oraz wykorzystaniem niety- } \\
\text { powej przestrzeni pofabrycznej. }\end{array}$ \\
\hline 9. & $22-24.09 .2017$ & FabLab Łódź & Robo Inspector Hackathon & $\begin{array}{l}\text { Zawody w nietypowej formule hackatho- } \\
\text { nu dla fanów robotyki, Arduino, elektroni- } \\
\text { ki oraz programowania. }\end{array}$ \\
\hline 10. & 5.10 .2017 & Teatr „Zamiast” & Premiera spektaklu „Soma” & $\begin{array}{l}\text { Aktywność kulturalna związana z ekspre- } \\
\text { sją twórczą oraz wykorzystaniem niety- } \\
\text { powej przestrzeni pofabrycznej. }\end{array}$ \\
\hline 11. & $7-8.10 .2017$ & $\begin{array}{l}\text { Fundacja In Search } \\
\text { Of... }\end{array}$ & Festiwal L'tronica & $\begin{array}{l}\text { 24-godzinna impreza skupiona wokół } \\
\text { muzyki elektronicznej i sztuki dźwięku. }\end{array}$ \\
\hline 12. & 2.11.2017 & FabLab Łódź & IV edycja kursu podstaw krawiectwa & Kurs praktyczny z podstaw krawiectwa. \\
\hline
\end{tabular}

Źródło: opracowanie własne na podstawie stron internetowych organizatorów.

ostatni opis wydarzenia odbywającego się w tej przestrzeni został dodany 24.04.2015 r. Więcej informacji można wyczytać z tekstów zamieszczanych przez konkretne firmy branży kreatywnej w Wi-Ma na ich stronach internetowych lub w portalu społecznościowym. Prezentowane w tab. 1 wydarzenia wpisują się zarówno w kategorię rekreacji twórczej w klasycznym rozumieniu, jak i twórczego podejścia do organizacji rekreacji, gdzie w sposób oryginalny i wartościowy proponowane są interesujące przedsięwzięcia.

Wymienione wydarzenia $\mathrm{w}$ większości były organizowane przez firmy branży kreatywnej, zlokalizowane na terenie Wi-Ma, rzadziej byli to organizatorzy z zewnątrz. Autorka dokonała wyboru proponowanych inicjatyw na podstawie opisanych wcześniej kryteriów twórczości.
Na stronie profilowej Wi-Ma w portalu Facebook można zapoznać się z recenzjami, napisanymi przez osoby, które odwiedziły to miejsce. Zdecydowana większość oceniających (29 osób) przyznała Wi-Ma aż pięć gwiazdek, znacząco mniej (siedem osób) - cztery gwiazdki. Najniższą ocenę - jedną gwiazdkę - przyznały cztery osoby. Warto jednak dodać, że tylko recenzje, w których najlepiej oceniono to miejsce, posiadają opis. Poniżej zamieszczono wybrane recenzje z roku 2017 (https://www.facebook.com/pg/wima. $\mathrm{hq} /$ reviews...):

23 stycznia 2017: „Wi-Ma to miejsce, które przyciąga. 5 lat temu - kiedy wszystko się powoli rozkręcało - zacząłem wynajmować tam pomieszczenie. Niestety WIMĘ musieliśmy opuścić, ale od tamtej pory regularnie bywam na różnych megaciekawych 
spotkaniach, imprezach, ale też tylko po to, żeby się przejść i powdychać ten kreatywny klimat. Miejsce na 5 z plusem! Brawo Wi-Ma, brawo wszyscy budujący ten klimat i brawo Pan Zaręba, który systematycznie spełnia swoją wizję!"

15 września 2017: „Klimat jest! Oby coraz więcej inicjatyw rozkręcało się w tej lokalizacji!"

1 sierpnia 2017: „Uwielbiam to miejsce”.

\subsection{WYNIKI WYWIADU SWOBODNEGO}

Spotkanie z prezesem (współudziałowcem) Wi-Ma Stanisławem Zarębą odbyło się 14.04.2016 r. Na podstawie przygotowanej dyspozycji autorka artykułu przeprowadziła wywiad swobodny, aby poznać opinię rozmówcy na temat celu i rodzaju działań prowadzonych w Wi-Ma ZPT, sieci współpracy oraz odbiorców proponowanych wydarzeń. Przez ponad dwie godziny rozmowy prezes Zaręba podzielił się z autorką swoją wizją Zakładów Przemysłów Twórczych, historią ich powstania oraz opisem aktualnych wyzwań i przedsięwzięć.

Po zagrożeniu upadłością, znalezieniu nowego inwestora oraz wyprzedaniu maszyn udało się spłacić długi firmy. Wtedy zaczęto zastanawiać się, co zrobić z tak olbrzymią przestrzenią. Jej część udało się wydzierżawić, jednak p. Zaręba, wykorzystując swoje bogate doświadczenie, które zdobył jako działacz ruchu młodzieżowego oraz polityk, postanowił otworzyć tę przestrzeń dla młodych - dać im możliwość realizowania własnych pomysłów. Co więcej, rozmówca wyraził przekonanie, że w ten sposób spłaca dług, który zaciągnął u innych ludzi, oraz że jest to jego obywatelska powinność. Podczas różnego rodzaju spotkań (np. Regionalnego Kongresu Kultury czy na konferencjach) apeluje o traktowanie młodzieży poważnie, ponieważ jak sam stwierdził:

Jeżeli ktoś dostaje więcej, niż się spodziewa, to stara się później udowodnić, że na to zasługiwał [rozmówca].

Zasadniczą ideą, która przyświeca p. Zarębie, jest stworzenie miejsca otwartego dla młodzieży oraz sprzyjającego współdziałaniu pokoleń - aby młodzi i seniorzy czerpali od siebie. Podkreśla także, jak ważne jest uczenie młodych ludzi tolerancji, otwartości na innych, bez narzucania własnego zdania, aby samodzielnie wzmacniali swoje poglądy, umieli je konfrontować oraz ich bronić we współczesnych realiach. Poczucie wartości wspólnej pracy powinno także sprzyjać tworzeniu społeczeństwa obywatelskiego, a wszystko po to, aby budować lepszą Polskę - rozmówca nie boi się użyć takich sformułowań. Jego ambicją jest zgromadzenie w Wi-Ma „masy krytycznej intelektu młodych Polaków”, którzy zmienią ten świat na taki, w jakim oni chcą żyć. Prezesowi zależy, aby otwierać się na inicjatywy oddolne, przyjmować je, wspólnie mierzyć się z pomysłami i zainteresowaniami młodych. Ze swojej strony oferuje własny czas i doświadczenie.

Głównymi inicjatorami oraz organizatorami wydarzeń w Wi-Ma są młodzi ludzie oraz funkcjonujące już w tej przestrzeni grupy kreatywne. W przekonaniu prezesa Zaręby młodzi przychodzą niepewni i obawiają się walczyć o swoją wolność. Przytoczył on ciekawy przykład: uczniowie III LO w Łodzi chcieli zorganizować bal dla osób z pierwszej klasy, ale nie udało im się uzyskać wsparcia ani ze szkoły, ani z domów kultury czy z kościoła. Rozmówca podkreśla, że młodzi czują, że się od nich tylko wymaga, a nikt ich nie słucha. Najczęściej z pomysłami przychodzą do niego uczniowie, studenci, czy też osoby tuż po studiach, z odwagą prezentując swoje poglądy. Jak twierdzi prezes Zaręba, są to ludzie z różnym doświadczeniem - zarówno artyści, jak i technicy spotykają się tam, tworząc grupy kreatywne. Najprężniej działające, według niego, to FabLab Łódź oraz PEVT. Zależy mu także na znalezieniu osób, które chciałyby wesprzeć firmę w podejmowaniu sensownych działań prospołecznych. W jego przekonaniu ważne jest, aby realizowane $\mathrm{w}$ tej przestrzeni przedsięwzięcia miały także społeczną wartość. Poza wymienionymi inicjatorami wydarzeń pojawiają się także jednorazowi organizatorzy, tacy jak np.: Urząd Marszałkowski, rady osiedli, koła naukowe, zaprzyjaźnieni twórcy łódzkich festiwali.

W przekonaniu prezesa Zaręby w Wi-Ma odbywa się bardzo dużo wydarzeń, jednak odkąd przestał działać Łącznik, jest ich znacznie mniej. Łącznik to restauracja, która w dzień pełniła funkcję baru i kawiarni, a wieczorami i przy różnych okazjach zamieniała się w ośrodek działań kulturalnych. W opinii rozmówcy główna oś działalności skupia się wokół podejmowanych przez grupy kreatywne przedsięwzięć, typu Łódzki Gam Jam czy festiwal Musica Privata. Ponadto grupy te zorganizowały wspólnie letnie zajęcia dla dzieci ze świetlic środowiskowych. Przestrzeń Wi-Ma wykorzystana była także podczas organizacji Festiwalu Myślenia Projektowego, Łódź Design Festivalu, Foto Day i Fotofestiwalu. Wi-Ma została zaproszona do projektu partnerstwa w ramach objęcia przez miasto Aarhus tytułu Europejskiej Stolicy Kultury 2017 o nazwie „Partnerstwo z kulturą na rzecz przyszłości Aarhus i HollyWoodge”.

Miejsce to sprzyja także organizacji alternatywnych przedsięwzięć. Niejednokrotnie spotykali się tutaj fani muzyki techno, Wi-Ma uznwawano także za swego rodzaju centrum łódzkiego hip-hopu. Zaangażowane zespoły współtworzyły interesującą mozaikę w podziemnym przejściu dla pieszych pod ulicą Piłsudskiego przy ulicy Konstytucyjnej. Przestrzeń pofabryczna Wi-Ma wykorzystywana jest również jako plener fil- 
mowy. Realizowane są tutaj etiudy studentów łódzkiej filmówki. Kręcono tu także sceny do filmów Miasto '44 i Powidoki oraz do serialu Komisarz Alex.

Rozmówca stwierdził, że odbiór proponowanych wydarzeń w Wi-Ma jest coraz szerszy, zauważył postęp liczebny. Trzeba jednak dodać, że wynajęcie przestrzeni obiektu nie jest proste, bowiem organizatorzy sami muszą zadbać o porządek, zorganizowanie toalet, zapewnienie kontenerów na śmieci i posprzątanie po wydarzeniu. Wi-Ma tylko wspiera, udostępnia przestrzeń, ale przekazując odpowiedzialność za miejsce, chce działać wychowawczo. Wi-Ma nie prowadzi żadnego biura impresaryjnego.

Lista współpracowników Wi-Ma jest bardzo długa. Warto chociażby wspomnieć o podpisanych listach intencyjnych z Akademią Sztuk Pięknych, Państwową Wyższą Szkołą Filmową, Telewizyjną i Teatralną, Społeczną Akademią Nauk, Wyższą Szkołą Informatyki. Częstymi gośćmi są także harcerze (m.in. z Hufca ZHP Łódź-Widzew). Prezes nawiązuje również współpracę z Uniwersytetem III Wieku i Radą Miasta Seniorów. Współdziała na stałe ze Stowarzyszeniem Topografie, Stowarzyszeniem PosŁódź czy Film Commission. Negatywnie jednak oceniana jest relacja z władzami miasta. Według rozmówcy taka współpraca nie istnieje. Dodaje, że podatki od nieruchomości wzrosły o 300\%. Narzeka, że władze miasta rozdają wprawdzie tzw. lokale dla kreatywnych, ale według niego autentyczni kreatywni są w Wi-Ma:

Jesteśmy tylko broszką na marynarce. Nikt się do nas nie odzywa [...]. My jesteśmy autentyczni, nie chcemy nikogo oszukać. Chcemy być partnerem i być tak samo traktowani.

Prezes Zaręba pokłada jednak nadzieję w programie rewitalizacji Łodzi, upatrując $w$ nim szansę na rozwój Wi-Ma. Rozmówcy bardzo zależy na tym, aby bez względu na przyszłe funkcje tej przestrzeni czy możliwe inwestycje, pozostały istniejące struktury młodych kreatywnych, pomimo że najczęściej ich działania nie generują zysku:

Tutaj ludzie tworzą własne warsztaty, za własne pieniądze, z własnych pomysłów, to jest wartość [...]. Chcę pokazać, że $\mathrm{w}$ starych murach $\mathrm{z}$ nowymi pomysłami, ambicją i pracowitością, konsekwencją w dążeniu do celu młodego pokolenia, mogą oni tworzyć coś dla siebie oraz użytecznego społecznie.

W swojej wizji dalszego rozwoju Wi-Ma p. Zaręba podkreśla konieczność trwania w wartościach, także europejskich, oraz pamiętania o tożsamości Łodzi wielonarodowej. Marzeniem prezesa jest zorganizowanie wydarzenia, w którym cztery chóry łódzkich uczelni wyższych, stojąc w czterech częściach parku Wi-Ma, odśpiewałyby Ode do radości w czterech językach, nawiązujących do tożsamości narodów, które tworzyły Łódź: polskim, niemieckim, rosyjskim i żydowskim.

Chciałbym, żeby było to przekazem o rozumieniu naszej tożsamości oraz otwartości na Europę.

\subsection{WNIOSKI}

Zakłady Przemysłów Twórczych Wi-Ma to z jednej strony trudny przykład. Na co dzień miejsce to jawi się jedynie jako siedziba firm, czy też swoisty inkubator branży w tzw. sektorze kreatywnym. W mediach rzadko pojawiają się informacje o prowadzonej tam działalności rekreacyjnej, a miejsce nie tętni życiem. Wi-Ma niejako „ożywa” od wydarzenia do wydarzenia. Ponieważ jest to przestrzeń prywatna, podlegająca pod zarząd, nie wydaje się kojarzona jako miejsce codziennej rekreacji mieszkańców czy turystów. Ponadto jej przyszłość nie jest jasna, zarówno pod względem planowanych inwestycji, udziału w programie rewitalizacyjnym, jak i możliwości finansowych. Z uwagi na aktualny stan budynków zapewnienie bezpieczeństwa w wynajmowanych lokalach może być niemożliwe bez podjęcia działań remontowych. Obawę także budzi wciąż zmieniająca się moda na spędzanie czasu wolnego. Być może niebawem Wi-Ma zostanie zastąpiona przez inne miejsce - alternatywne, ciekawsze, a może zmienią się potrzeby odbiorców proponowanych przez nią wydarzeń? Biorąc pod uwagę ostrzeżenie R. WINIARSKIEGO (red. 2011), który podkreślał, że czas wolny charakteryzuje się płynnością, mobilnością i powszechnością, tym bardziej nie można mieć pewności, jaka będzie przyszłość Wi-Ma. Dostrzegalna jest niska jakość promocji wydarzeń, a brak stałego miejsca spotkań w postaci klubu, restauracji czy baru może zadecydować o powolnym zanikaniu przywoływanego w recenzjach „kreatywnego klimatu”.

$\mathrm{Z}$ drugiej strony niebagatelną wartością Wi-Ma jest autentyczność funkcjonujących w niej grup. Tak zwane grupy kreatywne tworzą pasjonaci, którzy z własnej woli, pasji, często także z własnych środków proponują niebanalne przedsięwzięcia kulturalne - co podkreślał rozmówca. Nagromadzenie twórczych osób oraz twórczych inicjatyw w przestrzeni Wi-Ma sprawia, że miejsce to zaprasza do niestandardowych form rekreacji, takich jak: warsztaty krawieckie, tapicerstwa, bębniarstwa czy prezentacja niszowych filmów oraz spektakli teatralnych. Interesujące jest także łączenie ze sobą różnych form aktywności, np: zajęcia plastyczne połączone z zajęciami z elektryczności czy robotyki. Charakterystyczne dla Wi-Ma jest także poszukiwanie alternatywnych przedsięwzięć kulturalnych - szczególnie dotyczących tworzenia i promowania muzyki techno czy hip-hopu. Otwartość zarządu na nowe inicjatywy przyciąga młodych ludzi 
do zmierzenia się z własnymi marzeniami. Zatem to nie tylko organizatorzy proponowanych przedsięwzięć w Wi-Ma, ale także jej zarząd stanowią przykład osób twórczo podchodzących do organizacji rekreacji.

Zaprezentowane wyniki przeprowadzonego studium przypadku obrazują praktyczny wymiar potencjału twórczego podejścia do organizacji rekreacji oraz nowych form rekreacji twórczej. Wi-Ma Zakłady Przemysłów Twórczych to miejsce realizacji niekomercyjnych działań, którym przyświeca chęć wypełnienia misji, czyli dzielenia się swoją pasją. Warto zwrócić uwage na charakter organizowanych tu wydarzeń rekreacyjnych. Ich wyjątkowość często spełnia kryteria twórczego wytworu opisanego przez K.J. SzMIDTA (2013) czy E. NĘCKĘ (2001). Szczególnie mocno podkreślana przez rozmówcę sensowność organizowanych inicjatyw oraz nawet wychowawczy charakter wspólnej pracy nawiązują do opisanych kryteriów twórczości.

O sile przyciągania tego miejsca, jak pokazują komentarze odwiedzających, decyduje swoisty klimat. Intrygujące wykorzystanie przestrzeni postindustrialnej na przykładzie Wi-Ma może stanowić zachętę do dalszych rozważań nad znaczeniem zagospodarowania przestrzeni rekreacyjnej dla aktywności twórczej. Elementy przestrzeni pofabrycznej Wi-Ma stają się ważnym i inspirującym motywem przyciągania zarówno twórców-organizatorów, jak i odbiorców aktywności rekreacyjnej. Potwierdza to tezę D. STEVENSON (2006), że przedsięwzięcia rekreacyjne organizowane są często w specjalnych, rozrywkowych i kreatywnych strefach, a dzięki temu potencjał rozwoju jednostek może przełożyć się na lepszą jakość życia codziennego mieszkańców miast. Jak zauważa D. WANTUCH-MATLA (2016), atrakcyjność przestrzeni kreatywnej polega na różnorodności jej funkcji oraz bodźców oddziałujących na człowieka i przyciągających go. Przebywanie $\mathrm{w}$ tego typu miejscach daje szansę na nowe przeżycia i odczucia. Inspirując się opisanymi wcześniej wywiadami, zrobionymi przez J. WHITING i K. HANNAM (2015), warto byłoby przeprowadzić badania nad funkcjonowaniem użytkowników zaprezentowanej w studium przypadku przestrzeni rekreacyjnej.

Przytoczone studium przypadku pozwala na sformułowanie kilku uogólnień:

1) wnioski teoretyczne:

- wykorzystanie w badaniach nad rekreacją szerszego rozumienia przymiotnika "twórczy”,

- aktualizacja definicji rekreacji twórczej,

- analiza przestrzeni rekreacji twórczej,

- pogłębiona analiza funkcji wychowawczej rekreacji;

2) wnioski praktyczne:

- przeprowadzenie badań nad innymi przykładami przestrzeni rekreacji twórczej,
- analiza istotnych zmiennych dla powstawania i rozkwitu przestrzeni rekreacji twórczej.

\section{PODSUMOWANIE}

Rekreacja ma ogromny potencjał kształtowania osobowości. Odpowiedzialne i niekonwencjonalne podejście do organizacji rekreacji, aby nie sprowadzać jej tylko do łatwej rozrywki i wypoczynku, to wyzwanie współczesności. Twórcza postawa w organizacji rekreacji może sprzyjać rozwijaniu wszystkich opisywanych w literaturze rodzajów rekreacji - zarówno fizycznej, jak i psychicznej.

Wraz ze zmieniającym się stylem życia społeczeństwa rośnie potrzeba aktualizacji definicji rekreacji twórczej. Zaprezentowane studium przypadku łódzkich Zakładów Przemysłów Twórczych Wi-Ma obrazuje nietypowe oraz interesujące formy i rodzaje rekreacji, niemieszczące się już w zastałych definicjach. Dokonany przez autorkę przegląd literatury polskiej i zagranicznej skutkuje uwypukleniem niezbadanego jeszcze przez polskich naukowców potencjału rekreacji twórczej. Jej analizę warto byłoby przeprowadzać, opierając się na opisanych kryteriach twórczego wytworu.

Dokonane studium przypadku podkreśliło także istotną płaszczyznę dalszej analizy współczesnych form rekreacji, szczególnie rekreacji twórczej. Niebagatelne tło stanowi bowiem wykorzystywana przy jej organizacji przestrzeń rekreacyjna. W toku badań nad znaczeniem przestrzeni rekreacyjnej warto byłoby wykorzystać pojawiające się coraz liczniejsze opracowania dotyczące zagospodarowania przestrzeni miejskich - przestrzeni publicznych, czy też przestrzeni czasu wolnego. M. DEREK (2011) nazywa przestrzeń czasu wolnego nową siłą miastotwórczą w kulturze i rozrywce. Sposób wykorzystywania czasu wolnego staje się źródłem samorealizacji człowieka. Przestrzeń czasu wolnego odgrywa coraz istotniejszą rolę w miejskim krajobrazie. Często też wykorzystywane są w tym celu nowe przestrzenie, np. dawnych terenów przemysłowych (DEREK 2014). Warto byłoby przeprowadzić badania nad rolą lub znaczeniem przestrzeni - jej organizacji i zagospodarowania dla rozwoju różnych form aktywności rekreacyjnej.

Obecnie jakość przestrzeni publicznej jest ważnym kryterium rankingowym w wyścigu miast o najlepsze warunki i jakość życia mieszkańców (WANTUCH-MATLA 2016). Współczesna rekreacja powinna w sposób odpowiedzialny służyć rozwojowi człowieka, wykorzystywać wartościowe elementy otoczenia, aby zgodnie z przesłaniem uznanego architekta i urbanisty (GEHL 2013, s. 7) zadbać o ludzi i cenne życie między budynkami. 


\section{PRZYPISY}

1 Autorka używa w artykule nazwy własnej "Zakłady Przemysłów Twórczych Wi-Ma", jednak ma świadomość występującego w niej błędu gramatycznego. Rzeczownik "przemysł", jak wiele popularnych rzeczowników w języku polskim (np. „polityka”, , aktywność”, ,twórczość”), nie może bowiem występować w liczbie mnogiej, gdyż jej nie ma.

2 Zob. więcej: Potencjaty przemystów... (2014).

\section{BIBLIOGRAFIA}

BABBIE E., 2007, Badania społeczne w praktyce, Wyd. Naukowe PWN, Warszawa.

BACHVAROV M., DZIEGIEĆ E., 2005, The relation between the concepts of recreation and tourism, "Turyzm”, 15, 1/2, s. 79-93.

BONISŁAWSKI R., PODOLSKA J., 2008, Spacerownik łódzki, Agora, Łódź. CREEK J., 2008, Creative leisure opportunities, "NeuroRehabilitation”, 23, IOS Press, s. 299-304.

CZAJKOWSKI K., 1979, Wychowanie do rekreacji, Wydawnictwa Szkolne i Pedagogiczne, Warszawa.

DEMEL M., HUMEN W., 1970, Wprowadzenie do rekreacji fizycznej, Sport i Turystyka, Warszawa.

DEREK M., 2014, Miejska przestrzeń czasu wolnego, [w:] M. Madurowicz (red.), 2014, Kształtowanie współczesnej przestrzeni miejskiej, Wyd. Uniwersytetu Warszawskiego, Warszawa, s. 210-217.

DEREK M., 2011, Przestrzeń czasu wolnego w przestrzeni publicznej miasta, [w:] I. Jażdżewska (red.), Człowiek w przestrzeni publicznej miasta, Wyd. Uniwersytetu Łódzkiego, Łódź.

GEHL J., 2013, Życie między budynkami. Użytkowanie przestrzeni publicznych, Wyd. RAM, Kraków.

HUNNICUTT B.K., 2006, The history of western leisure, [w:] Ch. Rojek, S.M. Shaw, J. Veal (eds.), A handbook of leisure studies, Palgrave Macmillan, Basingstoke, s. 55-56.

ISO-AHOLA S.E., JACKSON, E., DUNN, E., 1994, Starting, ceasing, and replacing leisure activities over the lifespan, "Journal of Leisure Research", 26, s. 227-249.

KELLY J.R., 1996, Leisure, Allyn and Bacon, Boston.

KIEŁBASIEWICZ-DROZDOWSKA I., 2001, Teoria i metodyka rekreacji, Wyd. AWF, Poznań.

KONECKI K.T., CHOMCZYŃSKI P., 2012, Słownik socjologii jakościowej, Wyd. Difin SA, Warszawa.

KRAWCZYK Z., 2007, O turystyce i rekreacji. Studia $i$ szkice, Wyd. AlmaMer, Warszawa.

KUNICKI B.J., 1997, Rekreacja fizyczna, [w:] Z. Krawczyk (red.), Encyklopedia kultury polskiej XX wieku. Kultura fizyczna. Sport, Instytut Kultury, Warszawa.

KVAlE S., 2010, Prowadzenie wywiadów, Państwowe Wyd. Naukowe, Warszawa.

KWILECKA M., BROŻEK Z., 2007, Bezpośrednie funkcje rekreacji, AlmaMer Wyższa Szkoła Ekonomiczna, Warszawa.

MOKRAS-GRABOWSKA J., 2014, Przestrzeń turystyczno-artystyczna Łodzi na przykładzie Galerii Urban Forms, "Tourism/ Turyzm", 24/2, s. 23-30.

MOKRAS-GRABOWSKA J., 2015, Czas wolny $w$ dobie postmoderni$z m u$, „Folia Turistica”, s. 11-29.

NAPIERAŁA M., MUSZKIETA R., 2011, Wstęp do teorii rekreacji, Wyd. Uniwersytetu Kazimierza Wielkiego, Bydgoszcz.

NĘCKA E., 2001, Psychologia twórczości, Gdańskie Wyd. Psychologiczne, Gdańsk.
NIEDBALSKI J., 2013, Odkrywanie CAQDAS: wybrane bezptatne programy komputerowe wspomagające analizę danych jakościowych, Wyd. Uniwersytetu Łódzkiego, Łódź.

POEL H. VAN DER, 2006, Sociology and cultural studies, [w:] Ch. Rojek, S.M. Shaw, J. Veal (eds.), A handbook of leisure studies, Palgrave Macmillan, Basingstoke, s. 93-95.

Potencjały przemysłów kreatywnych w Łódzkim Obszarze Metropolitalnym. Raport, 2014, ASM - Centrum Badań i Analiz Ryn ku sp. z o.o., http://www.rot-lodkie.pl/mescms/attach ments/attaches/000/000/057/original/RAPORT_PRZE MYS\%C5\%81_KREATYWNE.pdf, 21.12.2017.

ROJEK CH., SHAW S.M., VEAL J. (eds.), 2006, A handbook of leisure studies, Palgrave Macmillan, Basingstoke.

SALERNO A., 2009, Consumer creative experience: the role of motivational orientation in creative leisure activity, , Recherche et Applications en Marketing", 24, 1.

SILVERMAN D., 2008, Prowadzenie badań jakościowych, Wyd. Naukowe PWN, Warszawa.

SIWIŃSKI W., PLUTA B. (red.), 2010, Teoria i metodyka rekreacji, Akademia Wychowania Fizycznego im. Eugeniusza Piaseckiego, Poznań.

STAKE R., 2009, Jakościowe studium przypadku, [w:] N.K. Denzin, Y.S. Lincoln (red.), Metody badań jakościowych, 1, Wyd. Naukowe PWN, Warszawa, s. 623-653.

STEVENSON D., 2006, The arts and entertainment: Situating leisure in the creative economy, [w:] Ch. Rojek, S.M. Shaw, J. Veal (eds.), A handbook of leisure studies, Palgrave Macmillan, Basingstoke, s. 354-362.

SzMIDT K.J., 2013, Pedagogika twórczości, Gdańskie Wyd. Psychologiczne, Gdańsk.

TOCZEK-WERNER S., 2005, Podstawy rekreacji i turystyki, Wyd. Akademia Wychowania Fizycznego, Wrocław.

TRNKA R., ZAHRADNIK M., KUŠKA M., 2016, Emotional creativity and real-life involvement in different types of creative leisure activities, "Creativity Research Journal”, 28, 3, s. 348-356, doi: 10.1080/10400419.2016.1195653.

WANTUCH-MATLA D., 2016, Przestrzeń publiczna 2.0. Miasto u progu XXI wieku, Księży Młyn Dom Wydawniczy, Łódź.

WARSZYŃSKA J., JACKOWSKI A., 1979, Podstawy geografii turyzmu, PWN, Warszawa.

WHITING J., HANNAM K., 2015, Creativity, self-expression and leisure, „Leisure Studies”, 34, 3, s. 372-384, doi: 10.1080/026 14 367. 2014.923494.

WINIARSKI R. (red.), 2011, Rekreacja i czas wolny, Oficyna Wydawnicza Łośgraf, Warszawa.

WOLAŃSKA T., 1971, Rekreacja fizyczna, Centralny Ośrodek Metodyki Upowszechniania Kultury, Warszawa.

ZARADKIEWICZ J., 2014, Z prezesa mecenas, „Łódź Kreuje Innowacje. Magazyn Informacyjny Miasta Łodzi" , 5, s. 22-27.

http:/ / uml.lodz.pl/dla-mieszkancow/o-miescie/strategia-lodzii-planowanie/strategia-zintegrowanego-rozwoju-lodzi-2020/, 21.12.2017.

http://Wi-Ma.pl/category/aktualnosci/, 8.11.2017.

http://Wi-Ma.pl/category/branza_kreatywna/, 9.11.2017.

http://Wi-Ma.pl/category/spis_firm/, 7.11.2017.

http:/ /Wi-Ma.pl/miejsce/, 04.11.2017.

http:/ /Wi-Ma.pl/miejsce/, 8.11.2017.

http://www.4kultury.pl/program, 9.11.2017.

http://www.dzienniklodzki.pl/kultura/a/wima-i-jej-perlyswietuja-od-doliny-kreatywnej-do-projektu-spolecznegozdjecia,10693709/, 8.11.2017.

http://www.kreatywna.lodz.pl/page/161,2012-Lodz-kreuje.html, 27.04.2016 
https://sjp.pwn.pl/szukaj/tw\%C3\%B3rczy.html, 23.12.2017.

https://trends.google.pl/, 13.11.2017.

https://www.facebook.com/events/1168018453318565/, 8.11.2017.

https://www.facebook.com/events/368459630180911/, 10.11.2017.

https://www.facebook.com/pg/FabLabLodz/events/?ref=page_ internal, 8.11.2017.

https://www.facebook.com/pg/FolkandRoll/events/?ref=page_ internal, 8.11.2017.
https://www.facebook.com/pg/TeatrZamiast/events/?ref=pa ge_internal, 8.11.2017.

https://www.facebook.com/pg/wima.hq/events/?ref=page_ internal, 8.11.2017.

https://www.facebook.com/pg/wima.hq/reviews/?ref=page_ internal, 09.11.2017.

Artykuł wpłyną: 23 grudnia $2017 \mathrm{r}$.

Zaakceptowano do druku: 26 lutego $2018 \mathrm{r}$. 